IFMIS is designed specifically for preparedness planning and initial attack dispatching. Using IFMIS, mobile crews and air tankers will be moved around the province as local weather and fire hazards dictate so that any fire can be "actioned" before it reaches 1.2 hectares in size. Fires that exceed this size are considered to have escaped initial attack, and have a greater potential to grow larger and become more expensive to control.

The Alberta Forest Service has assisted in the fine tuning of IFMIS, and tested it in operational trials last year. IFMIS was also tested operationally in the Prince Albert Forest Region in Saskatchewan in 1989. Potential cost savings, if IFMIS was to be deployed across Alberta, have been estimated at \$2-\$5 million annually depending on whether it's a "good" or "bad" fire year.
The latest version of IFMIS has been installed in the Whitecourt, Grande Prairie, Bow-Crow, Slave Lake, Lac La Biche and Athabasca Forests and at the Provincial Forest Fire Centre in Edmonton. It has also been installed in the Prince Albert Forest District, and will soon be installed in the Eastern Forest Region in Manitoba.

\section{Ontario Advanced Forestry Program}

Ontario is following the lead of British Columbia and initiating an advanced education program in Forest science for experienced foresters and resource managers. The program is aimed at developing resource managers' skills through comprehensive study of the biology, ecology, economics and silviculture of contemporary forest management. It will be offered annually in six two-week modules and administered jointly through Lakehead University and the University of Toronto. Academic standards will be rigorous with a demanding workload. Successful completion of all six modules will lead to professional recognition through a university certificate.

During 1990/91, the six modules will cover the following subject areas: (1) Autecology, genetics and population ecology, (2) Integrated forest ecosystems, (3) Managerial decision making, (4) Forest regeneration, (5) Managing stand dynamics, and (6) Forest issues.

Applications and further information are available from: Vic Weans, Director, Ontario Advanced Forestry Program, Ontario Ministry of Natural Resources, 258 Queen Street East, Sault Ste. Marie, Ontario, P6A 5N5.

\title{
Obituaries
}

\section{J.B. Millar 1909-1990 Neena, Wisconsin}

Age 80 , died Thursday morning, May 3 , 1990, at Theda Clark Regional Medical Center. He was born June 16, 1909, in Pembroke, Ontario, Canada, the son of the late John P. and Mary Astor (Shields) Millar. Mr. Millar was a 1931 graduate from the University of Toronto in Forestry. He was employed by Kimberly-Clark Corporation for 38 years in Ontario, the Upper Peninsula - Michigan, and Wisconsin in the Woodlands Division. He married Mary A. Bailey in June of 1934 in Pembroke. He was a 50 year member of the Canadian Institute of Forestry, and the Society of American Foresters. He was a charter member and past president of the Lake State Council of Industrial Foresters, a member of the Wisconsin Forests History Association, and the Wisconsin Woodland Owners Association, a charter member of the Appleton Curling Club, the Neenah Club, the A.A.R.P., and a member of Masonic organizations in Ontario, Neenah, and Menasha. $\mathrm{He}$ was a member of the First Presbyterian Church, Neenah. He was a former elder, trustee, and Sunday school teacher of that church. Survivors include his wife; two daughters: Dr. Susan (Kenneth) Wood, Vernon, New York; Mary (Philip) Helby, Yelverton, England: four sons: Rev. John (Robin) Millar, Winnipeg, Manitoba, Canada; William J. (Mary Ann) Millar, Manhattan Beach, California; Peter A. (Caroline) Millar, Anchorage, Alaska; Alex R. (Mary) Millar Long Beach, California; and 17 grandchildren.

\section{Allan John Cook 1920-1989}

After a short retirement, $\mathrm{Al}$ Cook, a long time member of the CIF, died suddenly in December 1989. Al grew up in Calgary where he attended the Crescent Heights High School from 1934 to 1939. After completing five years of military service he enrolled in the forestry program at the University of New Brunswick in 1946. He received his B.Sc.F. degree in 1950. For the next 15 years he was a research officer with the federal Forest Biology Division in Calgary. While working in Alberta Al took time out for graduate work at UNB where, in 1953, he received a M.Sc.F. degree.

As a research officer in Calgary, Al was involved with studies in forest growth and insect relationships, in site quality, and in tree physiology. In 1963 he moved to Newfoundland to work with the Newfoundland Forest Service as a regional forester at Corner Brook. In the same year he accepted a teaching position in the Pre-Forestry Program at Memorial University of Newfoundland in St. John's. Al was in charge of this program until his retirement in 1988. Besides teaching, Al was actively involved with the Canadian Institute of Forestry, the Newfoundland Forest Protection Association, and with the YMCA. He served for a number of years as a Director and Councillor of the Newfoundland Section of CIF and he was also the Chairman of the CIF's Education working Group. Al seldom missed the annual meeting or field trip of the Newfoundland Section. He was also a member and Vice-President of the Board of Directors of the YMCA in St. John's.

Al liked his job a great deal and spent considerable time counselling students. He was a great story teller and liked to engage in conversation with anyone concerning any topic. $\mathrm{He}$ visited us at the University frequently after his retirement. It is very unfortunate that he could not enjoy his retirement for a much longer time. His family and all of us who knew him will miss him a great deal.

Denes Bajzak, MUN.

\section{Daniel (Dan) Gagnon 1914-1990}

Le 18 janvier dernier, I'Institut Forestier du Canada perdait un membre de longue date M. Daniel Gagnon. Né en 1914, M. Gagnon a d'abord été officier dans la R.C.A.F. durant la Seconde Guerre Mondiale. Après la guerre, M. Gagnon a obtenu un baccalauréat en génie forestier de la Faculté de Foresterie et de Géodésie de l'Université Laval en 1950, puis une maîtrise en sciences forestières de la même institution en 1953.

M. Gagnon est entré en 1950 au service de la Direction des Forêts du Ministère du Nord Canadien et des Ressources Nationales, à Ste-Foy, qui allait bientôt se joindre au Laboratoire de Biologie Forestière pour former le Centre de Recherches Forestières des Laurentides. M. Gagnon y poursuivit une longue carrière, travaillant entre autres sur la nutrition des plantes, la fertilité des sites, et le lien entre la croissance des arbres et les facteurs environmentaux tels les précipitations. En 1979, M. Gagnon quittait le laboratoire pour prendre une retraite heureuse et bien remplie.

M. Gagnon était membre de I'IFC/CIF depuis 32 ans. II était aussi membre de I'Ordre des Ingénieurs Forestiers du Québec, et de I'Association Forestière Québécoise. 